\title{
Velocidade de fala em crianças com e sem transtorno fonológico $* * *$
}

\author{
Speech rate in children with and without phonological disorder
}

\author{
Haydée Fiszbein Wertzner* \\ Leila Mendes Silva**
}

\section{*Fonoaudióloga. Livre-Docente. Professora Associada do Departamento de Fisioterapia, Fonoaudiologia e Terapia Ocupacional da Faculdade de Medicina da Universidade de São Paulo. Endereço para correspondência: Rua Cipotanea, 51 - São Paulo - SP - CEP 05360-160 (hfwertzn@usp.br). \\ **Fonoaudióloga. \\ ***Trabalho Realizado na Faculdade de Medicina da Universidade de São Paulo.}

Artigo Original de Pesquisa

Artigo Submetido a Avaliação por Pares

Conflito de Interesse: não

Recebido em 25.06.2008.

Revisado em 05.12.08.

Aceito para Publicação em 03.02.2009.

\begin{abstract}
Background: speech rate in phonological disorders. Aim: to compare the performance of children with and without phonological disorders in different speech rate tests. Method: participants of this study were 20 children diagnosed with phonological disorders (PDG) and 20 with typical speech development (CG), aged 4 years to 10 years and 11 months, of both genders. Speech rate measurements (total durantion time, syllables per second and phonemes per second) were analyzed in two imitation tests, being one standard and the other based on phrases taken from the child's own speech, each composed of a short and a long sentence. Results: the CG presented a significantly better performance than the PDG, when considereing all of the mesurements applied to the standard imitation test and also when considering the total duration time of the long sentence in the self-imitation test. This indicates that the length and type of sentences influenced the performance of both groups. Conclusion: lower values of speech rate are observed for children with PD, participants of this study, due to possible language or motor deficits, although there is evidence of speech rate control due to the length of the sentence. All of the measurements indicated this difference, specially for the standard imitation test.
\end{abstract}

Key Words: Speech; Speech Disorders; Speech Articulation Tests; Speech Production Measurement.

\section{Resumo}

Tema: velocidade de fala no transtorno fonológico (TF). Objetivo: comparar o desempenho de crianças, com e sem transtorno fonológico, em diferentes tarefas de velocidade de fala. Método: participaram do estudo vinte crianças com diagnóstico de transtorno fonológico (GTF) e vinte crianças com desenvolvimento típico de fala (GC), com idade entre quatro anos a dez anos e onze meses, de ambos os sexos. As medidas de velocidade de fala (tempo total de duração, sílabas/segundo e fonemas/segundo) foram analisadas em duas provas de imitação, sendo uma padrão e outra baseada em frases retiradas do próprio discurso da criança, cada qual composta de uma sentença curta e outra longa. Resultados: o GC apresentou um desempenho significantemente melhor que o GTF em todas as medidas da prova de imitação padrão e também no tempo total de duração da sentença longa na prova de imitação de frases próprias, de forma que o tamanho e a tipologia das sentenças influenciaram o desempenho de ambos os grupos. Conclusão: verifica-se menores valores de velocidade de fala nas crianças com TF participantes deste estudo, em função de possíveis déficits lingüísticos ou motores, embora haja indícios de controle da velocidade de produção da fala em função do tamanho da frase. Todas as medidas mostraram tal diferença, especialmente na prova de imitação padrão.

Palavras-Chave: Fala; Transtornos da Fala; Testes de Articulação da Fala; Medida da Produção da Fala. 


\section{Introduction}

Information about speech rate is of relevance to the understanding of typical and disordered communication processes. It has been an important aspect to the differential diagnosis of possible subtypes of phonological disorder (PD) mainly to detect cases in which the motor difficulty to articulate sounds is presented (1). Some studies (26 ) have been showing differences in the speech productions values of children with PD compared to typically speech developing children.

Speech rate in young children is slower than in older children and adults, however, developmental pattern is non-linear (7-9). This increase in speech rate together with the decrease of production variability indicate maturation of the speech motor system and the interference of linguistic and cognitive variables that interacts within speech development (2-3, 5-8).

Speech rate can be measured manually using a chronometer or by temporal acoustical measures of computer programs in different speech tasks (7, 10-11). Structured situations with control of the occurrence of pauses, as in sentences repetition, minimize the influence of language formulation in the speech rate and better reflect the performance of the motor mechanism in the speech production (3).

This study aimed to describe and compare the performance of Brazilian Portuguese speaking children, with and without phonological disorder, in different tasks of speech rate to answer the following questions: Are children with phonological disorder slower than their peers without this disorder? What is the rate that better identify the slowness of speech? Does the type of test used to measure speech rate interfere in the result?

\section{Method}

This research was approved by the Ethics Committee for Research Projects Analysis of the Clinical Hospital and of the Medical School of the University of São Paulo, protocol number 225/05.

Participated in this study 40 boys and girls between 4 years and 10 years and 11 months. The phonologically disordered group (PDG) was constituted by 20 children that was referred to the Phonology Laboratory of the Department of Physiotherapy, Speech Pathology and Occupational Therapy of the Medical School University of São Paulo - and received the diagnostic of phonological disorder through the analysis of specific tests undergone in the same laboratory.

The control group (CG) was composed by 20 children of two public schools of the city of São Paulo, Brazil, matching the same age and gender of the children of the PDG. To be included in the research children could not have language or speech complaint, they all had to perform typically in the Phonology and Vocabulary tests of the Infantile Language Test ABFW (12), all of them had to be within the age range previously established and had to be Brazilian Portuguese native speaker, as well as their parents. All caregivers had to sign the informed consent permitting the participation of the children in the research.

Speech rate was based on the performance of two imitation tests with two sentences each: a short one (with less than six syllables) and a long one (with more than 6 syllables).

The first imitation test was the same for all subjects (standard imitation test - SIT) and consisted of the sentences "O cachorro fugiu" (The dog escaped) (a short sentence) and "Maria tem uma bola vermelha" (Maria has a red ball) (long sentence). Children had to imitate them after they are read by the examiner.

The second imitation test consisted of sentences imitation produced by each child (imitation tests - child sentences - IT - CS). Sentences were taken from the first three minutes of the spontaneous production of the child telling the fairy tale "Little Red Riding Hood". All data were videotaped and recorded. After selecting one short and one long sentence the examiner had to read then and the child had to imitate them. It is worth to mention that sentences were produced by the examiner with a colloquial language if used by the child. So, "a vovó estava dormindo" was produced this way instead of "a vovó estava dormindo" (Grandma was sleeping). Moreover, intelligible sentences of the PDG were selected but the examiner did not read them using the phonological processes the child presented.

Children were videotaped with a Sony Handycam DCR - DVD 403 with a mini Sony DVDRW (30 minutes $1.4 \mathrm{~GB} / \mathrm{Go}$ ) and their voice was recorded with a Semp Thoshiba Satelitte 605 notebook with a Sennheiser evolution 817 microphone to allow a better analysis of the children's production. Data collection for the PDG was conducted in a sound treated room and for the $\mathrm{CG}$ in a quiet room. 
For each sentence, it was counted its duration in seconds, the number of syllables and phonemes and the number of syllables and phonemes per minute. They were all analyzed through the WavePad 2.00 @NCH Swift Sound Software. Values for the speech rate tests - SIT and IT-CS - were calculated for $20 \%$ of the sample by a Speech and Language Pathologist and pos-graduation student with a $95 \%$ concordance with the first author.

The Mann-Whitney and the Wilcoxon tests were used considering a 5\% significant level ( $p$ ? 0.05 ) and $95 \%$ of confidence interval.

\section{Results}

The Mann-Whitney test was used to compare speech rate between the CG and the PDG for the two imitation tests.

Table 1 shows the values of mean, standard deviation and p-value for the SIT and IT-CS, of both groups in relation to the duration of the sentence in seconds, syllables/second and phonemes/second.

For the STI, the CG presented a significant better performance compared to the PDG in all measures. For the IT-CS this difference was detected only for the total duration of the long sentence, showing that the PDG needed a longer time. Apparently, there was no difference according to the type of measure that would better show difference between the two groups. All of them are of relevance to the analysis of data.

The Wilcoxon test was used to compare the performance of each group in different kinds of sentences, that is, according to the type of sentence (if standard or produced by the child) and to the length of sentence (long / short). Table 2 shows the p-values obtained through the mean values of syllables/second and phonemes/second. These variables affect the performance not only of the PDG but also of the CG, as only between the short sentences of the SIT and IT-CS there was no significant difference.

TABLE 1. Performance of the PDG and CG in the SIT and IT-CS.

\begin{tabular}{|c|c|c|c|c|c|c|c|c|}
\hline & & & & SIT & & & $\overline{\Pi \Gamma-C S}$ & \\
\hline & & & mean & $\mathrm{SD}$ & p-value & mean & $\mathrm{SD}$ & $\overline{p-v a l u e}$ \\
\hline \multirow[b]{6}{*}{ Short Sentence } & \multirow[b]{2}{*}{ Total duration } & $\overline{\mathrm{CG}}$ & 1.27 & 0.25 & \multirow[b]{2}{*}{$0.036^{*}$} & 1.13 & 0.26 & \multirow[b]{2}{*}{0.655} \\
\hline & & PDG & 1.38 & 0.2 & & 1.22 & 0.37 & \\
\hline & \multirow[b]{2}{*}{$\mathrm{syl} / \mathrm{sec}$} & $\overline{\mathrm{CG}}$ & 4.88 & 0.81 & \multirow[b]{2}{*}{$0.028 *$} & 4.62 & 0.83 & \multirow[b]{2}{*}{0.57} \\
\hline & & PDG & 4.37 & 0.67 & & 4.45 & 1.03 & \\
\hline & \multirow[b]{2}{*}{ Phon/sec } & $\overline{\mathrm{CG}}$ & 9.82 & 1.51 & \multirow[b]{2}{*}{$0.030^{*}$} & 9.3 & 1.36 & \multirow[b]{2}{*}{0.787} \\
\hline & & PDG & 8.73 & 1.44 & & 8.72 & 1.97 & \\
\hline & \multirow[b]{2}{*}{ Total duration } & $\mathrm{CG}$ & 1.99 & 0.28 & \multirow[b]{2}{*}{$0.020^{*}$} & 1.61 & 0.39 & \multirow[b]{2}{*}{$0.028^{*}$} \\
\hline & & $\overline{P D G}$ & 2.2 & 0.25 & & 1.98 & 0.71 & \\
\hline & \multirow[b]{2}{*}{$\mathrm{syl} / \mathrm{sec}$} & CG & 6.17 & 0.7 & \multirow[b]{2}{*}{$0.010^{*}$} & 5.29 & 0.78 & \multirow[b]{2}{*}{0.137} \\
\hline & & $\overline{P D G}$ & 5.53 & 0.64 & & 4.8 & 1.03 & \\
\hline & & $\overline{\mathrm{CG}}$ & 11.77 & 1.36 & \multirow[b]{2}{*}{$0.008^{*}$} & 10.41 & 1.56 & \multirow[b]{2}{*}{0.13} \\
\hline Long Sentence & phon/sec & PDG & 10.46 & 1.36 & & 9.53 & 1.93 & \\
\hline
\end{tabular}

Legend: $\mathrm{CG}=$ control group; $\mathrm{PDG}=$ phonologically disordered group; SIT = standard imitation test; IT $-\mathrm{CS}=$ imitation tests - child sentences; $\mathrm{SD}=$ standard deviation; $*$ = statistically significant value. 
TABLE 2. Comparisons between sentences of the imitation tests according to type and length (p-values).

\begin{tabular}{ccccc}
\hline & \multicolumn{2}{c}{ syl/sec } & \multicolumn{2}{c}{ phon/sec } \\
\hline & CG & PDG & CG & PDG \\
\hline SS SIT X SS IT-CS & 0.093 & 0.940 & 0.151 & 0.575 \\
\hline LS SIT X LS IT-CS & $<0.001^{*}$ & $0.001^{*}$ & $0.001^{*}$ & $0.01^{*}$ \\
\hline SS SIT X LS SIT & & & & \\
\hline SS PI-FP X LS PI-FP & $<0.001^{*}$ & $<0.001^{*}$ & $<0.001^{*}$ & $<0.001^{*}$ \\
& $0.004^{*}$ & $0.052^{*}$ & $0.001^{*}$ & $0.044^{*}$ \\
\hline
\end{tabular}

Legend: CG: = control group; PDG = phonological disorder group; SS = short sentence; LS = long sentence; SIT = standard imitation test; IT - CS $=$ imitation test - child sentence; $*=$ statistically significant value.

\section{Discussion}

One of the questions to be considered in the description of the phonological disorder is the relationship between cognitive, perceptive and motor aspects $(3,5-7,13-15)$.

As initially proposed, the present study verified that the speech rate of the PDG was slower in all tests and measures, although this difference was not always significant.

This findings is consistent with previous international researches in which different measures of speech rate (duration, number of syllables and of phonemes per second, quantity of phonetic units and syllables per word and sentences) are used to such analyzes but often raise difficulties when comparing data. But, in general, they show lower speech rate values in children with deficits in speech acquisition.

Speech rate results are shown in a follow-up study (3) of American children with phonological disorder background regarding the repetition of words within sentences. The group of children with residual speech errors (distortions) presented lower values of speech rate compared to children that suppressed speech disorder not only for syllables per second but also for phonemes per second. Author suggests that this decrease in speech rate may occur due to some way of compensation presented by these subjects, for example, due to some specific adjustment for a certain difficult sound or even due to the attempt to improve intelligibility.

Study for English speaking children considering the amount of syllables per words in phonologically disordered and in typically developing children - including those children that suppressed speech disorder - indicated that in the PDG there was no correlation between the increase of age and the increase of amount of syllables as detected in the control group. This fact can be related to co-existent deficits of the expressive language (for example, in lexicon or syntactic), to the severity of the disorder or even to the speech intelligibility (4).

Changes in speech rate affect their phonetic characteristics since producing faster speech, some small segments or even unstressed syllables can be deleted affecting intelligibility (13).

More and more acoustical and kinematic studies have been developed in the attempt of relating the subsystems of speech (phonation, intonation, articulation, rhythm, among others) with neural controls involved in the speech motor control (1516). Production of spoken language includes prelinguistic aspects (intension, pre-verbal message), language formulation (lexical selection and syntactic construction), phonological operations, phonetic specifications and motor control of the speech production system in order to generate acoustic patterns. On the other hand, comprehension of message involves inverse operations than those used in its formulation and production (14).

In relation to the performance of the groups in different types of tests it is observed that in the SIT the PDG presented higher duration for the total of sentences and lower means of speech rate in syllables per second and phonemes per second for both long and short sentences. For the IT-CS, the 
PDG presented lower values of speech rate; however, this difference was statistically significant only for the total duration of the long sentence.

This difference between performances of the groups concerning different types of sentences may indicate some relationship between linguistic aspects and speech rate as in the child's sentences, familiarity with the words may have influenced the production avoiding some difficulty that they could find in the standard sentences.

Study (5) comparing consecutive repetition of unfamiliar words, but of familiar phonetic context, in children with and without PD shows that both groups present a decrease in the speech rate during repetition. However, this phenomenon is more abrupt in children without PD. Curiously, the PD group presented in range higher speech rate in the first production. Authors relate this fact to a possible increase in muscular tension as an effort to produce the word. So, considering the progressive decrease of speech rate this is sometimes more often observed in children without PD. This fact can indicate that PD children use different strategies compared to their peer without PD suggesting a higher difficulty in the motor learning of new words.

Comparison of speech rate in Canadian children with typical speech development in different tests showed that linguistic context is as important variable as far as the spontaneous speech was faster than sentence imitation tests. This can be justified by the fact that children give more attention to imitation trying to repeat exactly what was said in contrast to the spontaneity of the speech in story telling (17). Well known sentences such as the repetition of "my name is ...." and the narrative of popular rhymes are produced with even higher speech rate compared to the spontaneous and sentence imitation (7), confirming the fact that familiarity with the context influences speech rate.

Study about orofacial kinematic behavior of 15 normal subjects in different speech tasks show temporal changes regarding the task. According to authors, different speech tasks activate different neural circuits and changes in the speech rate generally involve complex motor transformations (16).

Considering the length of sentences for the PDG and CG, long sentences in SIT and IT-CS were produced with higher quantity of syllables and phonemes per second in comparison to short sentences. This phenomenon can be related to strategies of speech rate control for the increase of speech production; especially for older children that would present a better motor control in as much as this study counted with children from 4 to 10 years that were grouped to be analyzed. Analyses distinguishing each age range would explain this fact with more detail. Studies with adults speakers (18) show higher speech rate in longer sentences as a possible result of a strategy of reduction of movements to increase co-articulation that was not detected in some studies with young children (7, 17) justifying that this ability seems to be related to the maturity of the speech motor control.

In an electromyographical analysis (EMG) of the labial muscular activity of children from 7 to 12 years and young adults during sentence repetition, verified a decrease in the variability of muscular production with the increase of age. According to authors this fact is related not only by maturation of the speech motor system but also to the neural processes that involve the planning and execution of the speech movements (8).

Table 2 also shows significant difference between long sentences of the SIT and IT-CS for the two groups, what was not detected for short sentences. This difference might have occurred due to the lack of control of the structural complexity of syllables in the IT-CS that was variable for each child, what can have lead to effect long sentences because they have more units.

\section{Conclusion}

Evidences indicate that speech rate is slower in PD children of this study due to possible linguistic or motor deficits, although there are indications of control of speech production rate according to the length of the sentence. In all this measures of speech rate analysis difference was reported specially for the standard imitation test. Because they are structured tasks with the possibility of control of complexity, imitation of sentences seems to be a useful instrument for the research of speech rate, thus important in the process of evaluation and treatment of children with PD. 


\section{References}

1. Shriberg LD. Diagnostic Classification of Five Subtypes of Childhood Speech Sound Disorders (SSD) of Currently Unknown Origin. Paper presented at the 2004 International Association of Logopedics \& Phoniatrics Conference, Brisbane, Australia, 2004.

2. Flipsen P Jr. Longitudinal changes in articulations rate and phonetic phrase lenght in children with speech delay. J Speech Lang Hear Res. 2002 Feb;45(1):100-10.

3. Flipsen P Jr. Articulation rate and speech-sound normalization failure. J Speech Lang Hear Res. 2003 Jun;46(3):724-37.

4. Flipsen P. Jr. Syllables per word in typical and delayed speech acquisition. Clin Linguist Phon. 2006;20(4):293301.

5. Smith AB, Robb MP. Durational characteristics of the first productions of novel trochees and iambs in children with and without speech delay. Clin Linguist Phon. 2005;19(1):1-14.

6. Peter B, Stoel-Gammon C. Timing errors in two children with suspected childhood apraxia of speech (sCAS) during speech and music-related tasks. Clin Linguist Phon. 2005;19(2):67-87.

7. Walker JF, Archibald LMD. Articulation rate in preschool children: a 3-year longitudinal study. Int J Lang Commun Disord. 2006;1-25. PrEview article.

8. Wohlert AB, Smith A. Development change in variability of lip muscle activity during speech. J Speech Lang Hear Res. 2002;45(6):1077-87.

9. Andrade CRF. Fluência. In.: Andrade, CRF, Befi-Lopes, DM, Fernandes, FDM, Wertzner, HF. ABFW: Teste de Linguagem Infantil nas Áreas de Fonologia, Vocabulário, Fluência e Pragmática. São Paulo: Pró-Fono; 2004.
10. Oliveira CR, Ortiz KZ, Vieira MM. Disartria: estudo da velocidade de fala/ Dysarthria: a speech rate study. Prófono. 2004;16(1):39-48.

11. Odell KH, Shriberg LD. Prosody-voice characteristics of children and adults with apraxia of speech. Clin Linguist Phon. 2001;15(4):275-307.

12. Andrade CRF, Befi-Lopes DM, Fernandes FDM, Wertzner HF. ABFW: Teste de Linguagem Infantil nas Áreas de Fonologia, Vocabulário, Fluência e Pragmática. São Paulo: Pró-Fono; 2004.

13. Kent RD, Read C. The Acoustic Analysis of Speech. San Diego: Singular Publishing Group; 1992. p. 152-3.

14. Kent RD. Research on speech motor control and its disorders: a review and prospective. J Commun Disord. 2000;33(5):391-428.

15. Kent RD, Kim YJ. Toward an acustic typology of motor speech disorders. Clin Linguist Phon. 2003 Sep;17(6):42745.

16. Tasko SM, McClean MD. Variations in articulatory movement with changes in speech task. J Speech Lang Hear Res. 2004;47(1):85-100

17. Walker JF, Archibald LMD, Cherniak SR, Fish VG. Articulation Rate in 3 - and 5 -year-old children. J Speech Lang Hear Res. 1992;35(1):4-13.

18. Van Lieshout PHHM, Starkweather CW, Hulstijn W, Peters HFM. Effects of linguistic correlates of stuttering on emg activity in nonstuttering speakers. J Speech Lang Hear Res. 1995;38(2):360-72. 